\title{
Some Preliminary Remarks on the World Council of Churches' Central Committee Statement on Religion and Violence
}

\author{
DANIEL BUDA*
}

\section{Introduction}

The Central Committee of the World Council of Churches (WCC CC) gathered from $22^{\text {nd }}$ to $28^{\text {th }}$ June 2016 in Trondheim, Norway, issued a Statement on Religion and Violence. The purpose of these brief preliminary remarks is to provide potential readers with background and bibliographical information and some personal comments on the text of the statement. All quotations of the statement in this article are taken from the text which is published after these preliminary remarks.

\section{Two recent examples of religiously based violence}

Using as motto the biblical text of James 3:18, the statement acknowledges as a matter of deep concern the grow and spread of violence in today`s world and the "ambiguous" connection of violence with religion. Two very recent examples of such type of violence are offered in the statement: the attack on His Holiness Patriarch Aphrem II Karim of the Syrian Orthodox Patriarchate of Antioch and All the East from 19 $9^{\text {th }}$ June 2016 and the socalled "Orlando nightclub shooting" from $12^{\text {th }}$ June 2016.

Just a few days before the WCC CC meeting started - and when in Trondheim the Executive Committee of WCC was meeting - the all world heard the shocking news that a suicide bomber targeted an event taking place in al-Wusta district of Qamishli, Syria, where several Christians leaded by His Holiness Patriarch Aphrem II Karim, Supreme Head of the Syrian Orthodox Church, were commemorating the Centenary of Assyrian Genocide. ${ }^{1}$ The attacker detonated the bomb at the entering of the venue, as secu-

Daniel Buda, Rev. PhD Habil Associated Professor at the "Andrei Şaguna" Faculty of Orthodox Theology, "Lucian Blaga" University of Sibiu, Romania; Programme Executive Coordinator for Church and Ecumenical Relations at WCC, Geneva. Address: WCC, Route de Ferney 150, 1211 Geneva 2, Switzerland; e-mail: daniel 77bde@yahoo.de.

1 Assyrian Genocide refers to the mass killings of Christian Assyrian population especially during the First World War in the Ottoman Empire and in Persia. It is connected with the better known Armenian and Greek genocides from the same period and area as the Assyrian genocide. For more details see L. H. Alexander, Thomas La Pointre, Douglas Irvin-Ericson, Hidden Genocides: Power, Knowledge, Memory, Rutgors University Press, 2013; Hanibal Tra-

RES 8 (2/2016), p. 308-318

DOI: $10.1515 /$ ress-2016-0022 
rity forces were controlling everyone who intended to enter the above-mentioned event. The attacker missed his target who obviously was Patriarch Aphrem II Karim; however three members of security forces died and other five were injured. WCC General Secretary, Rev. Dr Olav Fykse Tveit declared: "We are shocked by the news of this attack, apparently targeting the head of the Syriac Orthodox Church in the church's own homeland. It was an action of terror and violence to Christian communities. I condemn the ideology and intentions behind this attack, and call for prayer and support for the members and leaders of all religious minority communities in the region who are increasingly threatened and attacked." He also added: "While we thank God that Patriarch Aphrem was not harmed in this attack, our thoughts and prayers are especially for the families of those who lost their lives while protecting others from harm, and for the healing and recovery and healing of those who were wounded." He also called for "international solidarity and coherent collective action to bring an end to the conflict in Syria, and protection for the religious minorities throughout the region who are particularly targeted for violence and oppression." ${ }^{2}$ Other ecumenical organizations, like Conference of European Churches, ${ }^{3}$ Christian Conference of Asia, ${ }^{4}$ and many churches condemned the attack. Indeed, as the statement says, it was for "the first time that such an attack has been directed against a head of the church in such a way" during the conflicts in Iraq and Syria and since the existence of the terror organization Islamic State. However, the regions controlled by this terror organization and by other organizations with similar terrorist profile experienced a large range of violence in the name of a particular religion, i. e. the Islam. A large number of clerics and lay Christians were kidnapped or killed. The media made well-known the case of the two high ranking hierarchs, both metropolitans of Aleppo, His Eminence Boulos (Yazigi), from the Greek Orthodox Church of Antioch, and His Eminence Mor Youhanna Gregorios (Ibrahim) from the Syriac Orthodox Church of Antioch who were kidnapped in 2013 and since them there is no

vis, Genocide in the Middle East: The Ottoman Empire, Iraq, and Sudan, Durham, NC 2010; Anahit Khosoreva, "The Assyrian Genocide in the Ottoman Empire and Adjacent Territories", in: Richard G. Hovannisian (ed.), The Armenian Genocide: Cultural and Ethical Legacies, New Brunshwick, NJ 2007, p. 267-274.

2 See: http://www.oikoumene.org/en/press-centre/news/wcc-strongly-condemns-terror-attack-targeting-patriarch-ignatius-aphrem-ii

3 See: http://www.globalministries.org/cec_condemns_assassination_attempt_against_patriarch_of_syriac_orthodox_church

${ }^{4}$ See: http://cca.org.hk/home/news-and-events/cca-condemns-suicide-bombing-attack-onpatriarch-igantius-aphrem-ii/ 
evidence even if that they are still alive, but the number of Christian clergy, members of monastic communities, lay Christians who suffered kidnapping, exile or even martyrdom is much higher. Also unnumbered church buildings, sanctuaries, shrines, monasteries and other holy places of Christianity in the Middle East and of other religious communities, including Islam, were destroyed. Only the end of this conflict will allow a proper account of the in many ways unprecedented atrocities conducted by this terror organization in the region where Christianity has been born.

Under the name "Orlando nightclub shooting" is known the terror attack on a gay nightclub in Orlando, Florida, on June 12 2016. Omar Mateen a 29-years-old Muslin and security guard killed 49 people and wounded 53 others. As the statement says, "it was the worst mass shooting in $21^{\text {st }}$ Century US history." Regarding the reason of this attack, the statement mentions firstly that the attacker targeted "people on the basis of their sexual orientation" and is careful in naming it a religiously motivated act of violence by affirming that it was "apparently motivated, at least in part, by religious sentiments." It seems indeed that the "Orlando nightclub shooting" was a hate crime committed by a Muslim who pledged Islamic State allegiance against attenders of a gay nightclub which is, in the eyes of radicalized Muslims, a symbol of Western (religious and not only) decadence. Apart of these, the Orlando nightclub shooting seems to have a racial motivation too. On June $12^{\text {th }}$, the attacked night club was hosting a "Hispanic Night" and therefore most of the victims were of Hispanic origin. Therefore the careful association of the Orlando nightclub shooting with a religiously motivated violence in the statement is, in my opinion, well-motivated.

After these two very recent examples of obvious and of more implicit than explicit religiously motivated violence, the statement mentions the "religiously motivated violence by Boko Haram"5 which "affects Muslim and Christian communities throughout the West African region on a regular basis." Boko Haram seems to serve here, for good reasons, as a classical example of an organized promoter of religiously motivated violence. Indeed, by interpreting abusively the principals of Islam, Boko Haram kills, injures and destroys both Christian and Muslim lives and communities. Boko Haram was active initially in Nigeria but in the last period it spreads its terrorist activities also in the neighbouring countries. Therefore it is correct to affirm that Boko Haram is a terrorist organization which threats the West Africa region. This first paragraph of the statement ends with a new condemnation

5 See: Stuart Elden, Boko Haram - An Annotated Bibliography, published online on: https://progressivegeographies.files.wordpress.com/2014/06/bibliography-of-boko-haram25-june-2014.pdf 
of any religious justification of violence: "The World Council of Churches (WCC) condemns and denounces all such violent attacks and any religious justification or support for them.”

\section{WCC historic engagement for a world without religiously based violence}

The second paragraph of the statement resumes WCC efforts for promoting a world without religiously based violence. Indeed, since its foundation in 1948, WCC acted as "an instrument of peace." Following the example of "the Prince of Peace" who is the Lord Jesus Christ confessed by the entire WCC constituency as "God and Saviour," WCC understood as part of its very mission to stand for peace in the world. Being founded in a period when the entire world was terrified by the atrocities of two world wars and by forms of violence without precedent in world history, like the atomic bombing of Hiroshima and Nagasaki ${ }^{7}$ or the Holocaust (a form of violence with religious connotations!), the WCC "condemned hatred and violence directed against people on the basis of their racial or religious identity." The other pillar of this engagement for peace - apart of the Christological one which was mentioned before - was the anthropological principal that every human life has to be valued because it has an "inherent God-given dignity." Because in WCC understanding religion is a "powerful resource for peace" inter-religious cooperation for addressing conflicts in "multi-faith societies" was constantly promoted. One can understand that since WCC member churches are living in a gradually globalized world in which people of different faith and religious convictions are living together, WCC shall intensify its inter-faith efforts for promoting a world without religiously based violence.

\section{WCC recent commitments for peace}

After this summary of WCC historical engagement for peace, the statement mentions two recent WCC programs for promoting peace in the

\footnotetext{
6 Constitution and Rules of the World Council of Churches, I Bases, p. 1. See: http://www. oikoumene.org/en/resources/documents/assembly/2013-busan/adopted-documents-statements/wcc-constitution-and-rules

7 At the occasion of $68^{\text {th }}$ commemoration of atomic bombings of Hiroshima and Nagasaki, WCC General Secretary Rev Dr Olav Fykse Tveit issued a "public comment" in which affirms that even if "survivors' hope for all humanity: «No more Hiroshimas. No more Nagasakis»" was so far achieved, the last 68 years mean also an unacceptable proliferation of atomic weapons. East Asia is still a region threatened by atomic weapons. See the entire public comment on: http://www.oikoumene.org/en/resources/documents/general-secretary/ statements/68th-anniversary-of-atomic-bombings-of-hiroshima-and-nagasaki
} 
world. These are the ecumenical Decade to Overcome Violence (DOV) and the International Ecumenical Peace convocation (IEPC).

DOV 2001-2010 is the result of a call of the Eight Assembly of WCC, Harare, Zimbabwe, 1998, to "promote to the world a clear witness to peace, to reconciliation and nonviolence, grounded in justice." sents DOV as a period in which WCC confronted "persuasive violence in its many forms and expressions" and together with the entire ecumenical movement addressed "new challenges related both to the prevalence of intra-state conflicts and to the ambiguous role of religion in emerging forms of violent extremism and terrorism, as well as much older on-going threats to peace and to the security of people, families and communities."

IEPC held in Kingston, Jamaica, in 2001 harvested on the one hand the achievements of DOV and expressed, on the other hand, "an ecumenical commitment to <seeking the means to address violence and to reject war in favour of <Just Peace>." As the statements resumes, the Ecumenical Call to Just Peace articulated four dimensions of the concept of "Just Peace" which is called here "holistic". These are: (1) peace in the community; (2) peace with the Earth; (3) peace in the marketplace; (4) peace among the peoples. The statement mentions two aspects of presented in the Ecumenical Call to Just Peace: the acknowledgement that Christians have often been in the past "complicit in systems of violence" and the appealing to governments and "other groups" to "stop using religion as pretext for the justification of violence."

\section{$10^{\text {th }}$ WCC Assembly and its commitment for Just Peace}

The statement mentions the Pilgrimage of Justice and Peace for which the 10 ${ }^{\text {th }}$ WCC Assembly held in Busan in 2013 called upon and its adopted statement "The Way of Just Peace" 10 as steps forward for WCC in its engagement for peace in the world. It is mentioned also the statement entitled "The Politicization of Religion and Rights of Religious Minor-

8 The Decade to Overcome Violence (DOV), Churches Seeking Reconciliation and Peace. See: http://www.oikoumene.org/en/resources/documents/commissions/international-affairs/peace-anddisarmament/peace-concerns/the-decade-to-overcome-violence-dov-churches-seeking-reconciliation-and-peace. For more details regarding DOV, see: Richard D. N. Dickinson, "Overcoming Violence. A historical Reflection on the Decade to Overcome Violence", in: The Ecumenical Review 55 (3/2003), p. 192-225.

9 For more details regarding IEPC, see: http://www.oikoumene.org/en/resources/documents/wcc-programmes/public-witness-addressing-power-affirming-peace/report-of-the-international-ecumenical-peace-convocation

10 See: http://www.oikoumene.org/en/resources/documents/assembly/2013-busan/adopted-documents-statements/the-way-of-just-peace 
ities." 11 This text is review in the statement as the following: it expresses concern about "growing instances of hatred, intolerance and discrimination based on religion or belief in different parts of the world where religious minorities have been forced to live in vulnerable circumstances"; it highlights "a rising wave of religious extremism" and a growing threat of terrorism; it speaks against "the politicization of religion and the religionization of politics" which "have become pervasive phenomena in many parts of the world."

\section{Increase of religiously-justified violence}

After presenting and reviewing all these recent statements and documents issued by WCC in its effort for peace, the statement acknowledges that in spite all these "religiously-justified violence and hatred, oppression and attacks against people and communities on the basis of their religious identity have in the meantime only increased, and have become one of the dominating motifs of our times." Emblematic for this trend is the emerging of the terror organization Islamic State which unleashed an "exceptionally brutal violence ... against Yazigis, Christians and Muslims in the areas under its control in Syria and Iraq." One may add that the circle of violence unleashed by this terror organization reach more and more religious communities outside of their immediate control.

The statement mentions also that there is religiously-motivated violence in the world today as a feature of historical and current realities of "all major religions." Islam, Hinduism, Buddhism, Judaism and Christianity (in this order) are mentioned as examples. Special attention is given to "minority communities of many different religions in many parts of the world" which are "currently increasingly targeted by hate speech and violent attacks." While the special attention given to religious minorities as target of religiously-motivated violence is understandable since such form of violence is indeed a growing unacceptable reality, one can also comment that there is in the world today religiously-motivated violence conducted by religious minorities against majority. The text does not mention the growing violence of secular-atheistic groups against all forms of religion. This type of violence might be also integrated in the category of "religiously-motivated violence."

As these facts "must shake religious leaders and communities" and "oblige us all to enquire into what it is about religion and/or religious identity that is so susceptible to being linked to violence, either as protagonist/ perpetrator or as victim, and to interrogate our own traditions and interpretations for sources of violence against others." Seeking distance from those

\footnotetext{
11 See: http://www.oikoumene.org/en/resources/documents/assembly/2013-busan/adop-
} ted-documents-statements/politicisation-of-religion-and-rights-of-religious-minorities 
conducting violence in the name of our own religion is not a solution according to this statement, but "self-critical introspection" and "meaningful and effective interfaith dialogue and cooperation for the way of just peace."

\section{Call for concrete action}

The last part of the statement is a call in nine points for concrete action addressed to WCC member churches and ecumenical partners, namely "to give priority to reflecting on issues of religion and violence in their own contexts"; "to support fellow Christians who are suffering as a result of religiously-motivated violence"; "to extend such support not only to Christians but also to others who suffer similarly"; and "to speak words of Christian love for all into situations of violence and division" (point 2). In the following points of the final call, the statement requests WCC to decide to continue a special thematic importance of education for different categories of people in order to prevent radicalization which leads to violence (point 3-4); to address all forms of violence related in a way or another with religiosity (point 5); it highlights the importance of healing of trauma and healing of memories projects for overcoming the results of "religiously-motivated violence (point 6); it requests the WCC General Secretary to strengthen partnership with all partners involved in preventing atrocity crimes and to "tackle more explicitly the question of the relationship between religion and the public space, including freedom of choice, freedom of religion and equal citizenship rights" (point 7); calls upon "WCC and its member churches" to encourage inter-religious dialogue and cooperation (point 8); encourages the ecumenical movement in general to engage in practical cooperation with people and organizations of other religions and encourages the study and adoption active non-violent practices (point 9-10).

At the end of my preliminary remarks, I would like to add the information that along with this Statement on Religion and Violence, WCC $\mathrm{CC}$ received for adoption a programmatic document on the same theme. It contented a more consistent theological reflection on religion and violence as well as a larger range of examples how religion can be misused for violent and discriminatory purposes. This document prepared by the Department for Inter-Religious Dialogue and Cooperation in collaboration with the Church Commission for International Affairs of WCC was extensively discussed by a group of theologians in a meeting which took place in Geneva between $3^{\text {rd }}$ and $4^{\text {th }}$ March 2016. I had the honour to be part of this group as representative of the Secretariat of Faith and Oder Commission of WCC. An adjusted form of this document was presented to WCC CC in Trondheim for adoption. The Program Committee of WCCC CC, after discussing 
this document came with the following recommendation: "The programme committee recommends that the central committee:

1. refers the document to the executive committee for further improvement and further processing leading up to the next central committee.

2. requests the executive committee to take up religion and violence, non-violence and peace building as an important subject for the development of the Council's work in the coming years.

The simple fact that WCC CC had lively discussions around this document seems to me to be additional evidence that the theme of religion and violence with its complex and multiple facets need a consistent and deep reflection within ecumenical movement, so that the "ambiguous" connection of religion with all sorts of violence - as this statement affirms at its beginning - is getting clearer.

\section{Statement on Religion and Violence}

\section{Peacemakers who sow in peace reap a harvest of righteousness.} (James 3:18)

The persistence and spread of extremist violence in the world, and the ambiguous connections with religion, are causes of increasing alarm and concern today. This concern has again been sharpened and exemplified in very recent days by the 19 June attack targeting His Holiness Patriarch Aphrem II Karim of the Syrian Orthodox Patriarchate of Antioch and All the East, the first time that such an attack has been directed against a head of the church in such a way. Also, the apparently motivated, at least in part, by religious sentiments, the 12 June mass shooting in Orlando, Florida, targeting people on the basis of their sexual orientation resulted in 49 deaths and 53 injured, the worst mass shooting in $21^{\text {st }}$ Century US history. And, religiously motivated violence by Boko Haram affects Muslim and Christian communities throughout the West African region on a regular basis. The World Council of Churches (WCC) condemns and denounces all such violent attacks and any religious justification or support for them.

Throughout its history - following the example and in the mission of Jesus Christ, the Prince of Peace - the WCC has sought to be an instrument of peace in a world torn by violence. Founded in the aftermath of World War II, the WCC denounced warfare for the subjugation and domination of others. Shocked by the destruction unleashed by atomic weapons, it has worked consistently for disarmament and the elimination of all weapons of mass de- 
struction. Appalled by the Holocaust and by recurrent expressions of genocidal enmity, it has condemned hatred and violence directed against people on the basis of their racial or religious identity. Committed to the value of every human life, it has promoted dialogue and the peaceful resolution of disputes rather than the resort to armed force, and ultimately seeks to delegitimize the institution of war. Recognizing the inherent God-given dignity of every human being, it has worked for protection of the human rights of every person regardless of race, ethnicity, religion, gender or sexual orientation. Considering religion a powerful resource for peace, it has engaged in and promoted inter-religious cooperation to address conflicts in multi-faith societies.

Carrying forward its commitment to peace in a new historical and political context, the WCC launched the ecumenical Decade to Overcome Violence (DOV) 2001-2010, confronting pervasive violence in its many forms and expressions. Through the DOV, the WCC and the ecumenical movement sought to address new challenges related both to the prevalence of intra-state conflicts and to the ambiguous role of religion in emerging forms of violent extremism and terrorism, as well as much older on-going threats to peace and to the security of people, families and communities.

Convened to harvest the achievements of the DOV, the International Ecumenical Peace Convocation (IEPC) held in Kingston, Jamaica, in 2011, expressed an ecumenical commitment to "seeking the means to address violence and to reject war in favour of 'Just Peace"”. The Ecumenical Call to Just Peace articulated four dimensions of this holistic concept - peace in the community, peace with the Earth, peace in the marketplace, and peace among the peoples.

The Ecumenical Call to Just Peace acknowledged that Christians have often been complicit in systems of violence, injustice, militarism, racism, sexism, casteism, intolerance and discrimination, but that they seek forgiveness and transformation. It also appealed to governments and other groups to stop using religion as a pretext for the justification of violence.

At the $10^{\text {th }}$ WCC Assembly, Busan, 2013, WCC member churches committed themselves to moving together on a 'Pilgrimage of Justice and Peace'. The assembly adopted a statement on "The Way of Just Peace" in which this way was described as "a journey into God's purpose for all humanity and all creation" rooted in the hope of spiritual transformation.

The $10^{\text {th }}$ Assembly also adopted a statement on "The Politicization of Religion and Rights of Religious Minorities" in which concern was expressed about "growing instances of hatred, intolerance and discrimination based on religion or belief in different parts of the world where religious minorities have been forced to live in vulnerable circumstances." The statement 
highlighted "a rising wave of religious extremism" and a growing concomitant threat of terrorism. It spoke against "the politicization of religion and the religionization of politics" which "have become pervasive phenomena in many parts of the world".

Despite the concerns, commitments and hopes expressed in these initiatives and statements, religiously-justified violence and hatred, oppression and attacks against people and communities on the basis of their religious identity have in the meantime only increased, and have become one of the dominating motifs of our times. Emblematic of this trend is the emergence -especially since mid-2014 -of the so-called 'Islamic State' group and the exceptionally brutal violence it unleashed against Yazidis, Christians and Muslims in the areas under its control in Syria and Iraq.

Nevertheless, religiously-motivated violence is a feature of both the histories and current realities of all major religions - of Islam, Hinduism, Buddhism, Judaism and Christianity - and minority communities of many different religions in many parts of the world are currently increasingly targeted by hate speech and violent attacks.

Recognition of this fact must shake religious leaders and communities free from any complacency or excuse, and oblige us all to enquire into what it is about religion and/or religious identity that is so susceptible to being linked to violence, either as protagonist/perpetrator or as victim, and to interrogate our own traditions and interpretations for sources of violence against others. The easy path of seeking to distance one's own religion from those who have perpetrated acts of violence in its name is not an adequate or legitimate response to the gravity of this challenge. Frank and self-critical introspection is an essential foundation for meaningful and effective interfaith dialogue and cooperation for the way of just peace.

The WCC central committee, meeting in Trondheim,

Norway, 22-28 June 2016:

1. Considers that, particularly in view of the increasing significance of these matters in current world affairs, religious leaders and communities from all faith traditions are called to self-examination and reflection on the relationship between religion and violence, and to challenge interpretations and practices that support violence and hate speech against others and that threaten peace and social stability.

2. Calls on WCC member churches and ecumenical partners to give priority to reflecting on issues of religion and violence in their own contexts, taking seriously the need for openness to and appropriate support for those 
who may be seen as 'other' in each situation; to support fellow Christians who are suffering as a result of religiously-motivated violence; to extend such support not only to Christians but also to others who suffer similarly; and above all to speak words of Christian love for all into situations of violence and division.

3.Decides to continue a special thematic focus on the issue of peace building in contexts of religion and violence during 2017 within the framework of the Pilgrimage of Justice and Peace.

4. Encourages the exploration of the importance of education, including theological education and formation as well as formal and informal education of children, as a tool for preventing and countering radicalization, focusing on peace-affirming rather than violence-affirming strands.

5. Emphasizes the need for churches to recognize and address the pernicious persistence of sexual and gender-based violence, from the domestic setting to the field of armed conflict, including sexual harassment and abuse by religious leaders, and especially to confront and challenge any religious interpretations or traditions that encourage or tolerate sexual and

gender-based violence.

6. Stresses the importance of engaging in work and initiatives for the healing of those who have suffered trauma, including the healing of memories, as a result of religiously-motivated violence.

7. Requests the general secretary to strengthen partnerships and joint initiatives with ecumenical and inter-religious partners, the inter-governmental system and civil society partners aimed at preventing incitement to atrocity crimes, and to tackle more explicitly the question of the relationship between religion and the public space, including freedom of choice, freedom of religion and equal citizenship rights - constitutionally guaranteed - for all, regardless of religious affiliation.

8. Calls upon the WCC and its member churches to encourage and engage in forms of dialogue which address the difficult questions in inter-religious relationships, including the link between religious ideologies and violence, and the undervaluing of the contribution of women in some religious traditions.

9. Encourages members of the ecumenical movement to engage in, in addition to inter-religious dialogue, practical cooperation with organisations representing other religions on issues relating to justice, peace and the well-being of communities.

10. Encourages the study and adoption of the principles and practices of active non-violence, as the most legitimate and appropriate means of countering discrimination and oppression and of breaking the cycle of violence. 